\title{
PERANCANGAN UI/UX APLIKASI MY CIC LAYANAN INFORMASI AKADEMIK MAHASISWA MENGGUNAKAN APLIKASI FIGMA
}

\author{
M. Agus Muhyidin', Muhammad Afif Sulhan'2, Agus Sevtiana ${ }^{3}$ \\ Universitas Catur Insan Cendekia \\ Jl. Kesambi 202, Kota Cirebon, Jawa Barat. Telp (0231)220350 \\ e-mail: agusmuhyidin10@gmail.com ${ }^{1}$, sulhan.afif@gmail.com ${ }^{2}$, a.sevtiana@gmail.com ${ }^{3}$
}

\begin{abstract}
ABSTRAK
Universitas Catur Insan Cendekia sebagai institusi yang bergerak dalam bidang pendidikan telah memanfaatkan teknologi informasi terutama yang berkaitan dengan proses belajar dan mengajar. My CIC adalah aplikasi sistem informasi akademik mahasiswa berbasis web dengan tujuan memberikan informasi seputar akademik kepada mahasiswa. My CIC yang beralamat https://my.cic.ac.id/. Jumlah pengunjung website My CIC ini hanya meningkat pada saat-saat tertentu saja, hal ini dikarenakan informasi yang terdapat pada My CIC ini kurang lengkap. Selain itu terdapat beberapa permasalahan antara lain tampilan desain dari My CIC kurang menarik dan ada beberapa halaman \& tombol kurang di pahami oleh mahasiswa yang mengakses website My CIC. Dalam perancangan desain UI/UX prototype aplikasi My Cic ini penulis memberi solusi untuk merancang desain sebuah aplikasi my CIC dengan user interface dan user experience yang menarik, minimalis dan modern. Dalam perancangan ini software editing yang digunakan adalah Figma, dan didalam nya berisi terkait informasi akademik mahasiswa seperti profil mahasiswa, data nilai, KRS, jadwal kuliah, ujian online, diskusi kelas, kartu ujian, riwayat mengulang dan transaksi administrasi keuangan mahasiswa. Dengan perancangan ini diharapkan Universitas Catur Insan Cendekia tetap berupaya untuk penerapan teknologi dibidang pendidikan dan untuk meningkatkan kinerja, kualitas pelayanan, daya saing kualitas sumber daya manusia yang pada akhirnya akan menghasilkan lulusan (Output) yang berkualitas dan mampu memenangkan persaingan global.
\end{abstract}

Kata kunci: Desain, Aplikasi, UI/UX, Prototype, Teknologi

\begin{abstract}
Catur Insan Cendekia University as an institution that is engaged in education has utilized information technology, especially those related to the learning and teaching process. My CIC is a webbased student academic information system application with the aim of providing academic information to students. My CIC, which is located at https://my.cic.ac.id/. The number of visitors to the My Cic website only increases at certain times, this is because the information contained in My CIC is incomplete. In addition, there are several problems, including the appearance of the design of My CIC which is less attractive and there are several pages \& buttons that are not understood by students who access the My Cic website. In designing the UI / UX design for the My CIC application prototype, the writer provides a solution for designing the design of a my CIC application with an attractive, minimalist and modern user interface and user experience. In this design, the editing software used is Figma, and it contains student academic information such as student profiles, value data, KRS, class schedules, online exams, class discussions, exam cards, repetition history and student financial administration transactions. With this design, it is hoped that Catur Insan Cendekia University will continue to strive for the application of technology in the field of education and to improve performance, service quality, competitiveness in the quality of human resources which will ultimately produce quality graduates (Output) and be able to win global competition.
\end{abstract}

Keywords: Design, Application, UI/UX, Prototype, Technology

Perancangan UI/UX Aplikasi My CIC Layanan Informasi Akademik Mahasiswa Menggunakan Aplikasi Figma -( M. Agus Muhyidin, Muhammad Afif Sulhan, Agus Sevtiana) 


\section{PENDAHULUAN}

\subsection{Latar Belakang}

Di era modernisasi seperti sekarang, manusia sangat bergantung pada teknologi. Hal ini membuat teknologi menjadi kebutuhan dasar setiap orang. Dari orang tua hingga anak muda, para ahli hingga orang awam pun menggunakan teknologi dalam berbagai aspek kehidupannya. Teknologi di masa kini telah berkembang dengan pesat. Tak seperti waktu dulu, Teknologi sangatlah berpengaruh dalam aspek kehidupan manusia dan ikut berperan dalam kehidupan masyarakat luas khususnya peran teknologi di bidang pendidikan. Dalam pendidikan sendiri teknologi kini memiliki peranan tersendiri dalam proses belajar mengajar. (Tuti Setiawati : 2018)

Universitas Catur Insan Cendekia (CIC) Cirebon adalah salah satu perguruan tinggi swasta di kota Cirebon yang telah menerapkan sistem teknologi informasi. Universitas catur insan cendekia cirebon berdiri pada tahun 1984. Salah satu layanan teknologi informasi yang ada di Universitas Catur Insan Cendekia Adalah sistem informasi akademik mahasiswa yaitu (MY CIC).

MY CIC adalah aplikasi sistem informasi akademik mahasiswa berbasis web dengan tujuan memberikan informasi seputar akademik kepada mahasiswa. Dengan adanya MY CIC mahasiswa dapat mengetahui informasi yang berkaitan dengan akademik kampus seperti biodata mahasiswa, kuliah semester, daftar nilai dan transkrip nilai mahasiswa.

Melihat MY CIC ini masih berbasis web dan belum berbasis mobile device atau aplikasi. Dan menurut beberapa mahasiswa tampilan user interface dari website MY CIC ini kurang efektif dan efisien karena ada beberapa tombol/menu kurang di pahami oleh mahasiswa. Sejalan dengan itu fitur-fitur informasi yang berkaitan dengan akademik mahasiswa juga masih belum cukup lengkap seperti terkait dengan administrasi kampus antara lain administrasi keuangan, kartu rencana studi (KRS), jadwal kuliah, konsultasi mahasiswa, kartu ujian, kuliah semester dan riwayat mengulang masih belum ada dalam website tersebut. Website My CIC ini hanya berisi yang berkaitan dengan daftar nilai, transkrip, dan biodata mahasiswa saja.

Berdasarkan hasil wawancara dari beberapa mahasiswa Catur Insan Cendekia mengatakan bahwa tampilan dari website my cic ini kurang menarik dan membosankan. Oleh karena itu dalam Tugas Akhir ini penulis tertarik merancang desain User Interface dan User Experience sistem informasi akademik (My CIC) dengan menggunakan aplikasi Figma. Dengan penelitian ini, diharapkan aplikasi My CIC dapat menjadi akses utama semua informasi yang berkaitan dengan akademik mahasiswa dan memperbaiki tampilan My CIC menjadi lebih menarik dan modern dari segi Design User Interface dan User Experience yang sesuai dengan kebutuhan dan nyaman digunakan mahasiswa Catur Insan Cendekia Cirebon.

\subsection{Identifikasi Masalah} adalah :

Berdasarkan uraian latar belakang masalah di atas maka identifikasi masalah pada penelitian ini

1. Bagaimana cara merancang desain aplikasi sistem informasi yang dibutuhkan mahasiswa Universitas Catur Insan Cendekia?

2. Bagaimana cara merancang desain aplikasi MY CIC dengan tampilan User interface yang menarik dan modern dengan berbasis mobile device?

\subsection{Batasan Masalah}

Berdasarkan identifikasi masalah di atas, maka penulis membatasi masalah yang ada yaitu :

1. Perancangan desain UI/UX aplikasi my cic menggunakan figma.

2. Proses yang digunakan dalam merancang UI/UX aplikasi my cic ini menggunakan metode Prototyping.

3. Target audiens dalam perancangan ini ditunjukan pada mahasiswa Universitas Catur Insan Cendekia

\subsection{Tujuan}

Adapun tujuan penelitian ini adalah:

1. Memudahkan mahasiswa yang membutuhkan informasi terkait perkuliahan di kampus dalam satu aplikasi yaitu My CIC.

2. Memudahkan mahasiswa lebih nyaman dalam menggunakan aplikasi My CIC dengan tampilan user interface yang simple, menarik dan modern.

3. Menghasilkan prototype mobile apps My CIC yang dapat di kembangkan lebih lanjut dan bisa digunakan mahasiswa Catur Insan Cendekia. 


\section{KAJIAN PUSTAKA}

\subsection{Pengertian Perancangan}

Definisi Perancangan menurut Jogiyanto dalam bukunya "Analisis dan Desain" menjelaskan bahwa perancangan adalah tahap setelah analisis dari siklus pengembangan sistem yang dapat berupa penggambaran, perencanaan dan pembuatan sketsa atau pengaturan dari beberapa elemen yang terpisah ke dalam satu kesatuan yang utuh dan berfungsi, termasuk menyangkut mengkonfigurasi dari komponenkomponen perangkat lunak dan perangkat keras dari suatu system. (2005:196).

\subsection{UI/UX}

UI dan UX adalah singakatan dari User Interface dan User experience yakni merupakan sebuah tampilan visual dalam sebuah aplikasi atau alat pemasaran digital dalam bentuk website yang dapat meningkatkan brand yang dimiliki oleh bisnis atau perusahaan.

\subsubsection{User Interface (UI)}

UI atau User Interface adalah ilmu tentang tata letak grafis suatu web atau aplikasi. Cakupan UI adalah tombol yang akan diklik oleh pengguna, teks, gambar, text entry fields, dan semua item yang berinteraksi dengan pengguna. Termasuk layout, animasi, transisi, dan semua interaksi kecil. UI mendesain semua elemen visual, bagaimana pengguna berinteraksi dengan halaman web dan apa yang ditampilkan di halaman web. Elemen visual yang ditangani oleh seorang desainer UI adalah skema warna, menentukan bentuk tombol, serta menentukan jenis font yang digunakan untuk teks. Desainer UI harus bisa membuat tampilan bagus yang akan meningkatkan kesetiaan pengguna.

\subsubsection{User Experience $(\mathrm{UX})$}

Definisi UX atau user experience menurut Borrys Hasian ada bermacam-macam. Berdasarkan apa yang dikerjakan, desainer UX adalah orang yang membuat produk yang bermanfaat dan memvisualisasi user flow menjadi desain produk yang teruji dan indah. Desainer UX akan bekerja sama dengan tim-tim lain untuk mencari titik temu antara kebutuhan pengguna, tujuan bisnis dan kemajuan teknologi. Titik temu tersebut kemudian dijadikan sebuah produk yang bermakna, berguna, dan menyenangkan. Seperti namanya, desain yang dibuat oleh desainer UX akan menentukan mudah atau sulitnya user experience atau interaksi dengan web. Membuat wireframe atau mendesain mockup adalah salah satu kemampuan dasar yang harus dimiliki oleh seorang desainer UX.

\subsection{Elemen Dalam Desain}

Menurut Aryo Sunaryo (2002 : 5), mengatakan bahwa dalam menciptakan bentuk, berupa memilih unsur-unsur rupa, memadukan dan menyusunnya agar di peroleh bentuk yang menarik, memuaskan atau membangkitkan pengalaman visual tertentu. Tujuan mengorganisasikan unsur-unsur rupa adalah untuk mewujudkan nilai estetis. Unsur-unsur rupa tersebut antara lain :

\subsubsection{Titik / Point}

Titik adalah salah satu unsur visual yang wujudnya relatif kecil, dimana dimensi memanjang dan melebarnya di anggap tidak berarti. Titik cenderung di tampilkan dalam bentuk kelompok, dengan variasi jumlah, susanan, dan kepadatan tertentu.

\subsubsection{Garis / Line}

Garis dianggap sebagai unsur visual yang banyak berpengaruh terhadap pembentukan suatu objek sehingga garis, selain di kenal sebagai goresan atau coretan, juga menjadi batas limit suatu bidang atau warna. Garis dapat di tampilkan dalam bentuk lurus, lengkung, gelombang, zigzag dan lainnya.

\subsubsection{Bidang / Field}

Bidang merupakan unsur visual yang berdimensi panjang dan lebar. Di tinjau dari bentuknya, bidang bisa di kelompokkan menjadi dua, yaitu bidang geometri/beraturan dan bidang non geometri/tidak beraturan. Bidang geometri adalah bidang yang relatif mudah di ukur keluasannya, sedangkan bidang non geometri merupakan bidang yang relatif sukar di ukur keluasannya.

\subsubsection{Ruang / Space}

Ruang dapat di hadirkan dengan adanya bidang. Pembagian bidang atau jarak antar objek berunsur titik, garis, bidang dan warna. Ruang lebih mengarah pada perwujudan tiga dimensi sehingga ruang dapat 
dibagi dua, yaitu ruang nyata dan semu. Keberadaan ruang sebagai salah satu unsur visual sebenarnya tidak dapat di raba tetapi dapat di mengerti.

\subsubsection{Ukuran / Size}

Ukuran adalah unsur lain dalam desain grafis yang mendefinisikan besar kecilnya suatu objek. Unsur ini digunakan untuk memperlihatkan objek manakah yang kita mau tonjolkan karena dengan menggunakan unsur ini seorang desainer grafis akan dapat menciptakan kontras dan penekanan (emphasis) pada objek desain sehingga orang akan tahu skala prioritas objek yang akan dilihat terlebih dahulu dibandingkan yang lainnya, misalnya saja untuk ukuran suatu judul akan lebih besar dari skala objek yang lainnya.

\subsubsection{Warna / Color}

Warna sebagai unsur visual yang berkaitan dengan bahan yang mendukung keberadaannya ditentukan oleh jenis pigmennya. Kesan yang di terima oleh mata lebih ditentukan oleh cahaya. Permasalahn mendasar dari warna di antaranya adalah Hue (spektrum warna), Saturation (nilai kepekatan) dan Lightness (nilai cahaya dari gelap ke terang). Ketiga unsur tersebut memiliki niai 0 hingga 100, hal yang paling menentukan adalah lightness.

\subsubsection{Tekstur / Texture}

Tekstur adalah nilai raba dari suatu permukaan. Secara fisik tekstur di bagi menjadi tekstur kasar dan halus, dengan kesan pantul mengkilat dan kusam. Di tinjau dari efek tampilannya, tekstur di golongkan menjadi tekstur nyata dan tekstur semu. Disebut tekstur nyata bila ada kesamaan antara hasil raba dan pengelihatan. Sementara itu pada tekstur semu terdapat perbedaan antar hasil pengelihatan dan peraba.

\subsubsection{Huruf / Typography}

Dalam dunia desain grafis, tipografi di definisikan sebagai suatu proses seni untuk menyusun bahan publikasi menggunakan huruf cetak. Oleh karena itu, menyusun meliputi merancang bentuk huruf cetak hingga merangkainya dalam sebuah komposisi yang tepat untuk memperoleh suatu efek tampilan yang dikehendaki.

\subsection{Metode Prototype}

Prototype adalah model kerja dasar dari pengembangan sebuah program (software) atau perangkat lunak. Prototype dalam Bahasa Inggris "prototype" disebut juga dengan purwarupa. Prototype biasanya dibuat sebagai model untuk tujuan demonstrasi atau sebagai bagian dari proses pengembangan atau pembuatan sebuah software. Kata Prototype berasal dari Bahasa Latin, yaitu kata "proto" yang berarti asli, dan "typus" yang berarti bentuk atau model. Dalam konteks non-teknis, Prototype adalah contoh khusus sebagai wakil dari kategori tertentu.

Dalam bidang desain, Prototype atau purwarupa atau disebut juga dengan arketipe adalah bentuk awal sebagai contoh atau standar ukuran dari sebuah entitas. Sebuah Prototype dibuat sebelum dikembangkan atau justru dibuat khusus untuk pengembangan sebelum dibuat dalam skala sebenarnya atau sebelum diproduksi secara massal. Prototype adalah sebuah Javascript Framework yang dibuat untuk lebih memudahkan proses dalam membangun aplikasi berbasis web.

Metode protyping sebagai suatu paradigma baru dalam pengembangan sistem informasi, tidak hanya sekedar suatu evolusi dari metode pengembangan sistem informasi yang sudah ada, tetapi sekaligus merupakan revolusi dalam pengembangan sistem informasi manajemen.

\subsection{Software Editing}

\subsubsection{Figma}

Figma adalah salah satu design tool yang biasanya digunakan untuk membuat tampilan aplikasi mobile, desktop, website dan lain-lain. Figma bisa digunakan di sistem operasi windows, linux ataupun mac dengan terhubung ke internet. Umumnya Figma banyak digunakan oleh seseorang yang bekerja dibidang UI/UX, web design dan bidang lainnya yang sejenis.

Selain mempunyai kelengkapan fitur layaknya Adobe XD, Figma memiliki keunggulan yaitu untuk pekerjaan yang sama dapat dikerjakan oleh lebih dari satu orang secara bersama-sama walaupun ditempat yang berbeda. Hal tersebut bisa dikatakan kerja kelompok dan karena kemampuan aplikasi figma tersebut lah yang membuat aplikasi ini menjadi pilihan banyak UI/UX designer untuk membuat prototype website atau aplikasi dengan waktu yang cepat dan efektif.

\section{HASIL PENELITIAN}

Dalam proses ini merupakan tahap awal proses editing mulai dari membuka website editing figma di google.com dan proses menentukan dokumen yang akan di buat, import gambar, import logo, insert text, hingga peletakan tombol yang akan di gunakan dalam tampilan awal aplikasi ini. 
3.1. Proses mendesain

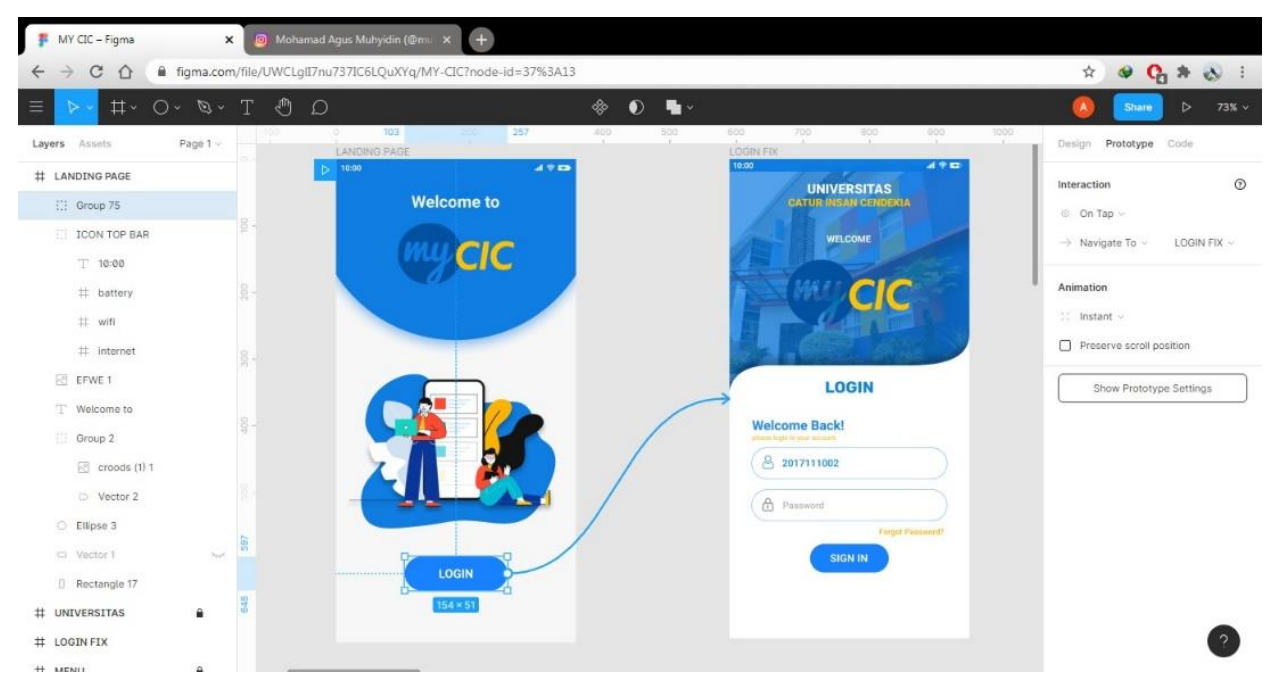

Gambar 1. Tampilan Awal > Tampilan Login

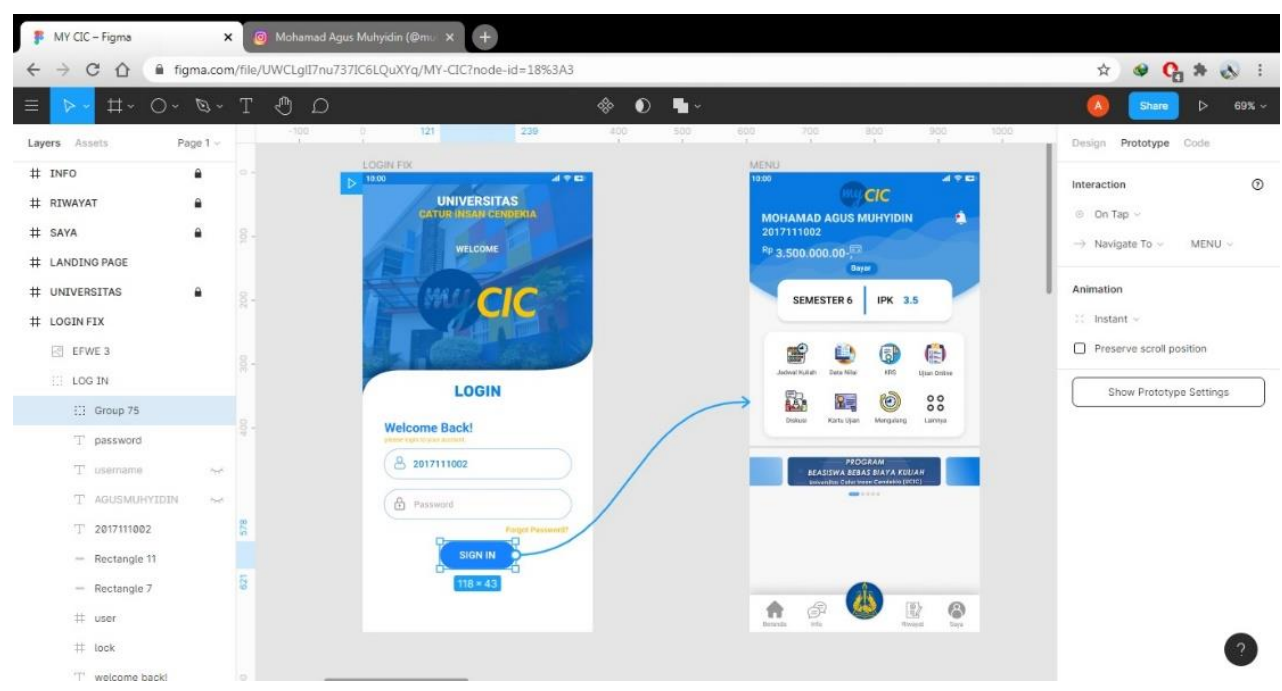

Gambar 2. Tampilan Login > Menu Utama 


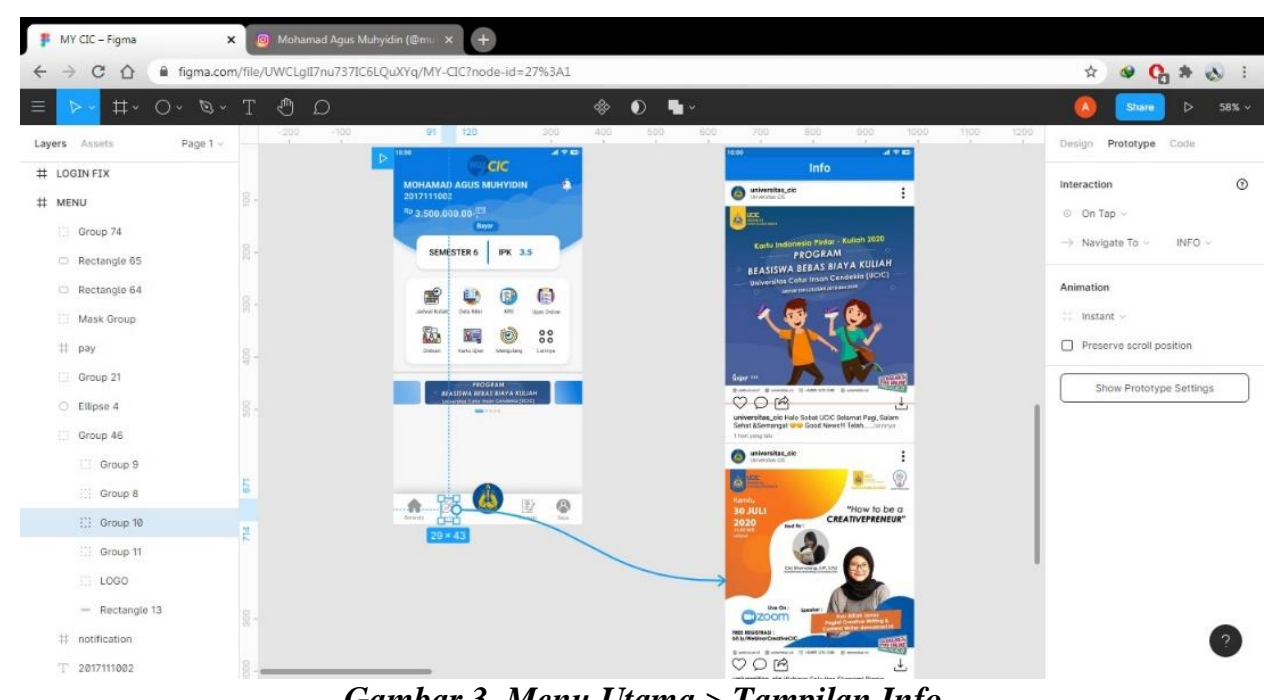

Gambar 3. Menu Utama > Tampilan Info

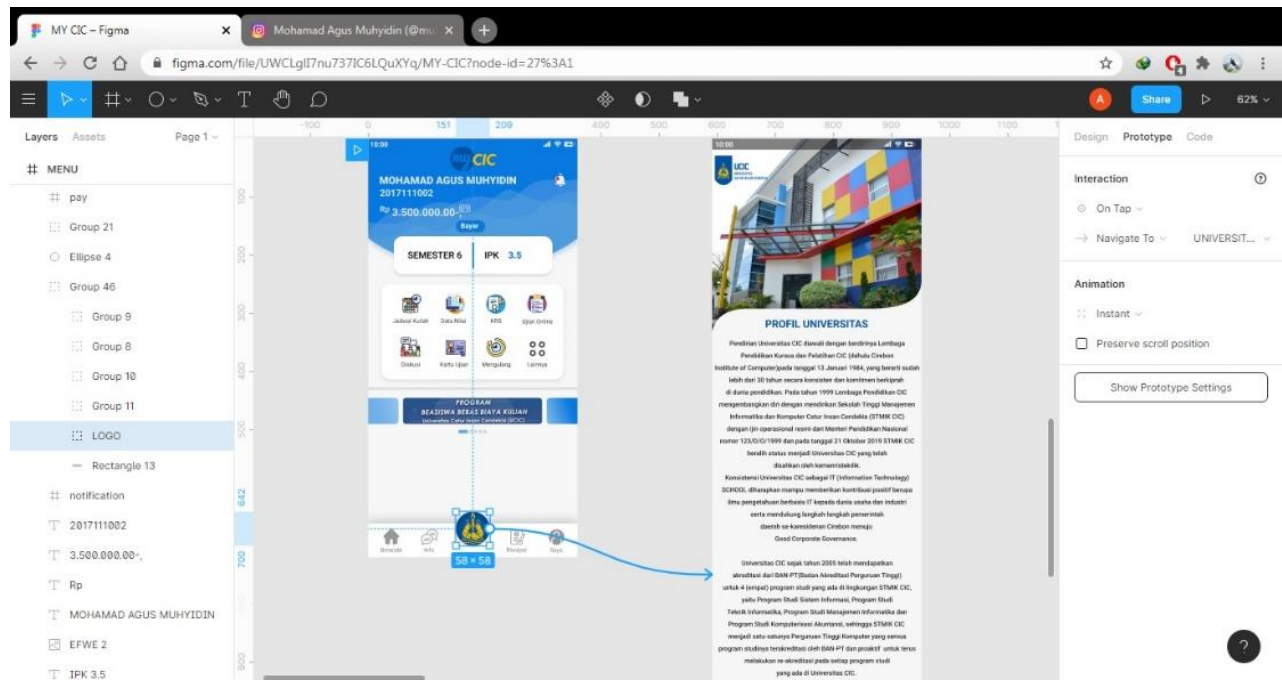

Gambar 4. Tampilan Menu Utama > Profil Universitas

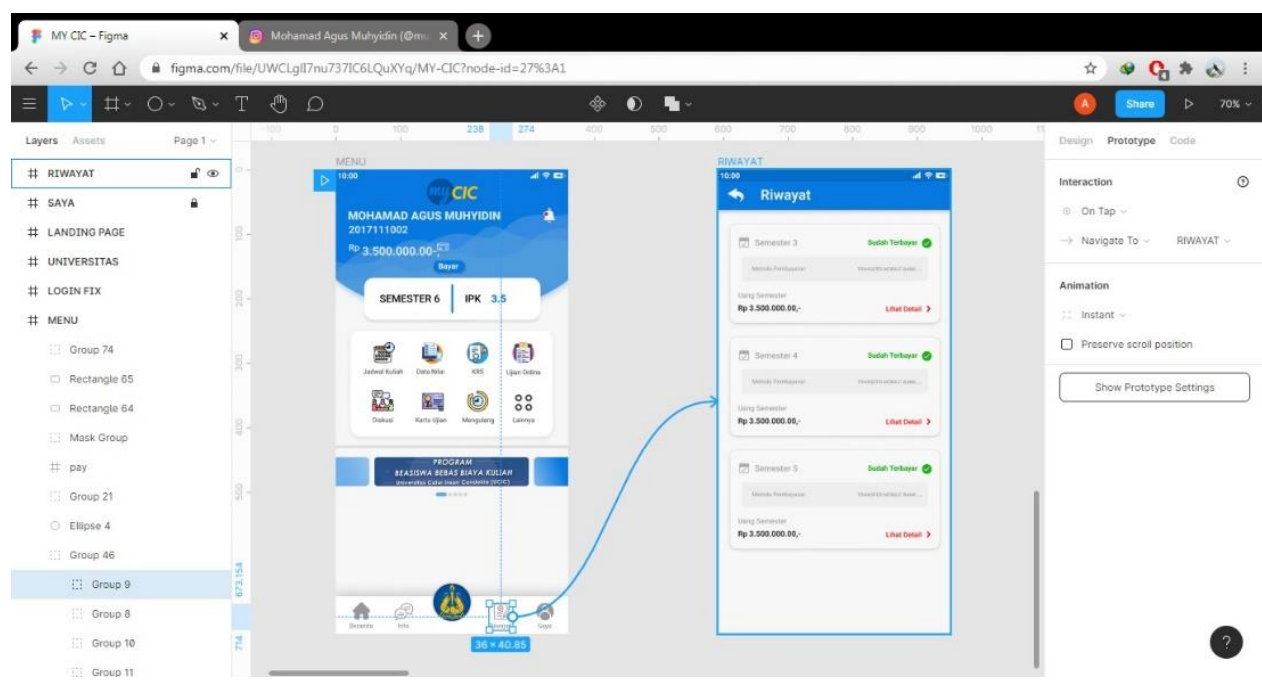

Gambar 5. Menu Utama > Tampilan Riwayat 


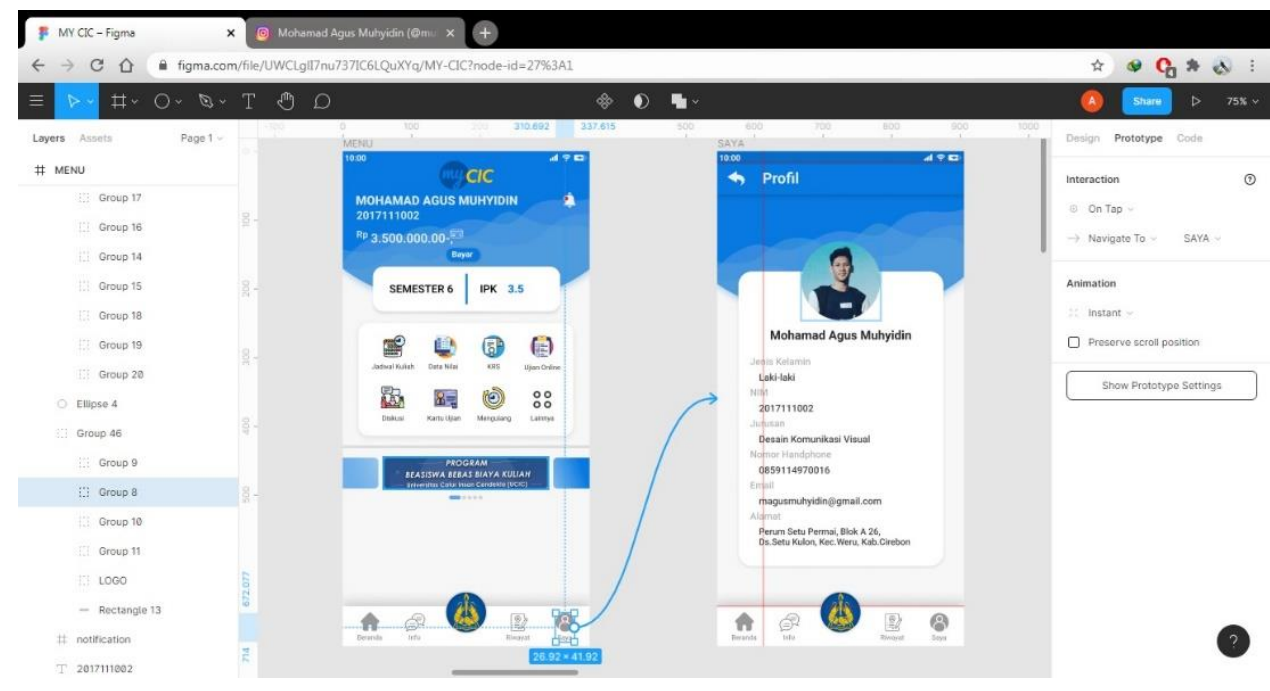

Gambar 6. Tampilan Menu Utama > Tampilan Saya

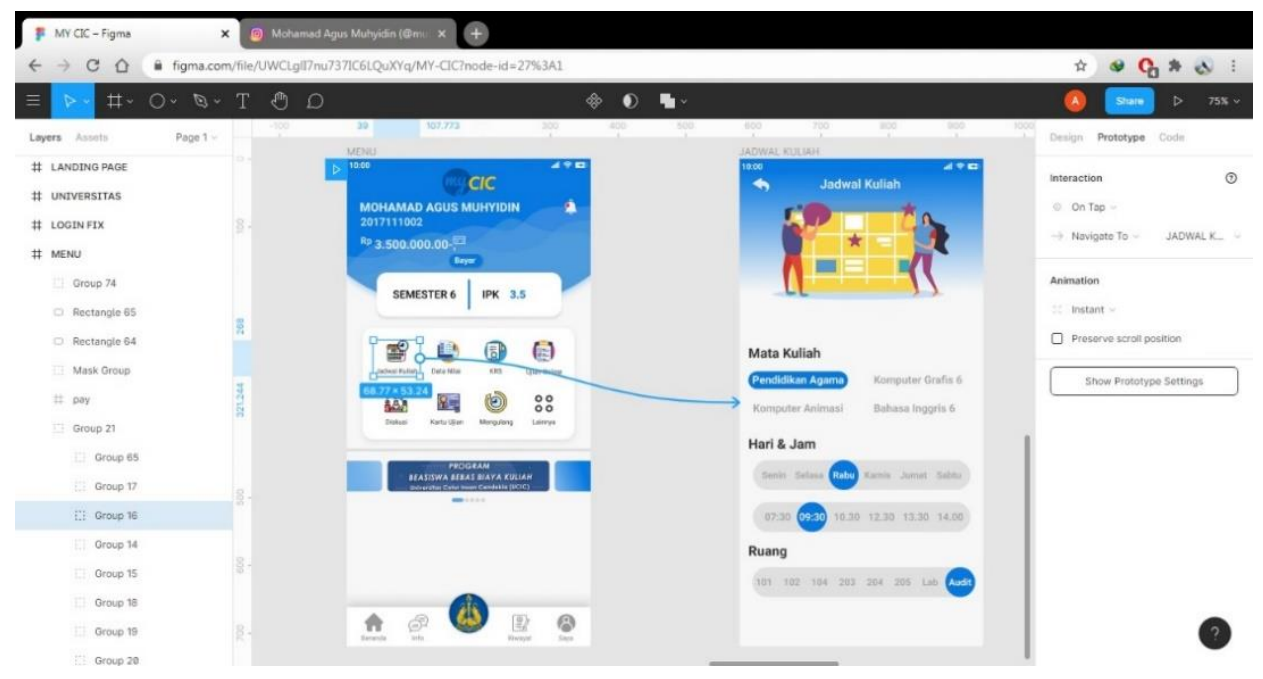

Gambar 7. Tampilan Menu Utama > Tampilan Jadwal Kuliah 


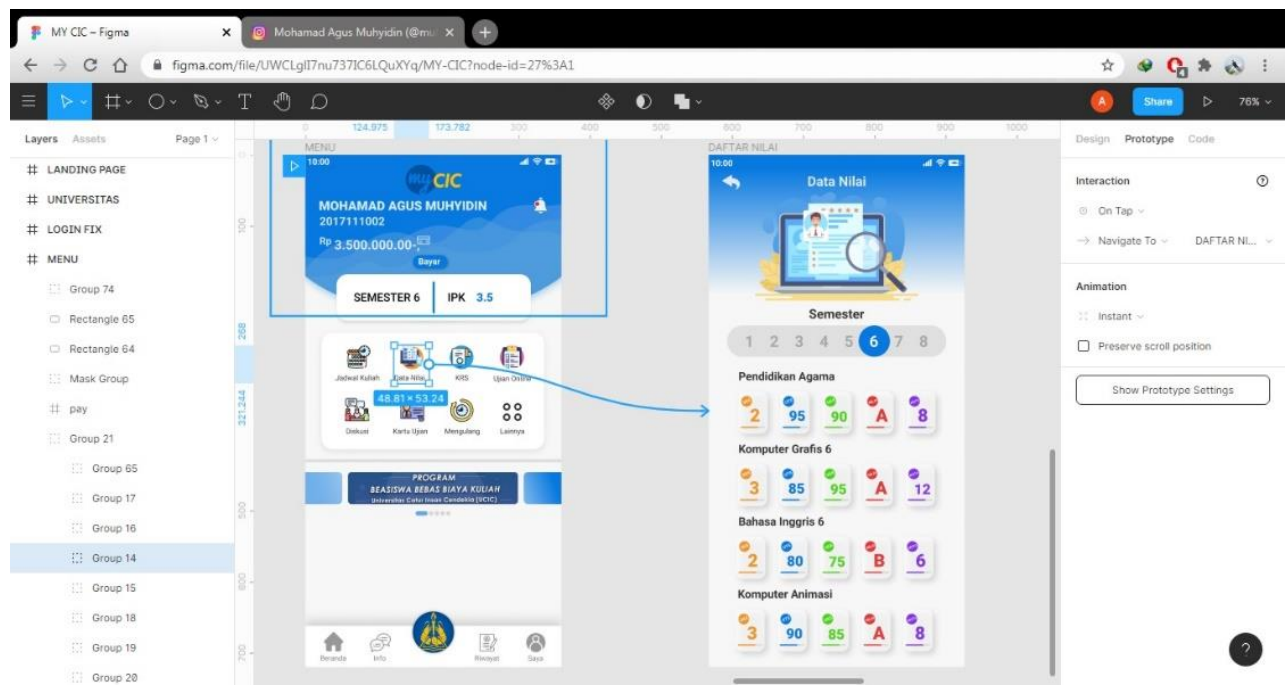

Gambar 8. Tampilan Menu Utama > Tampilan Data Nilai

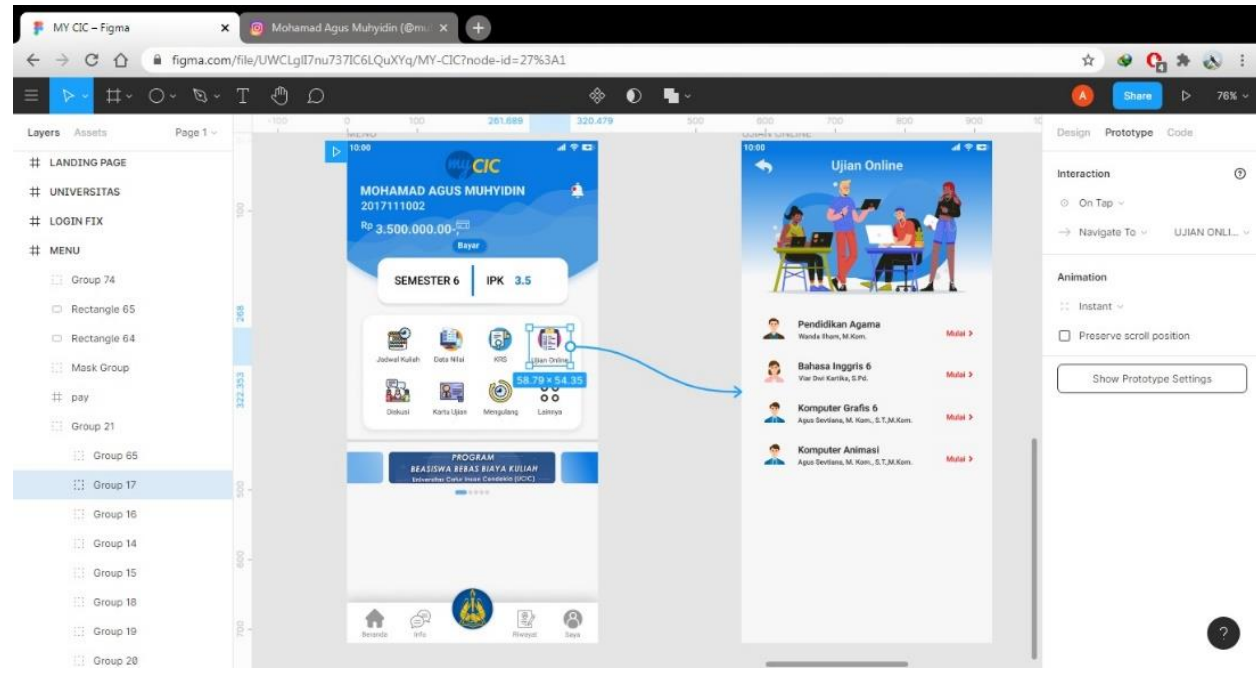

Gambar 9. Tampilan Menu Utama > Tampilan Ujian Online

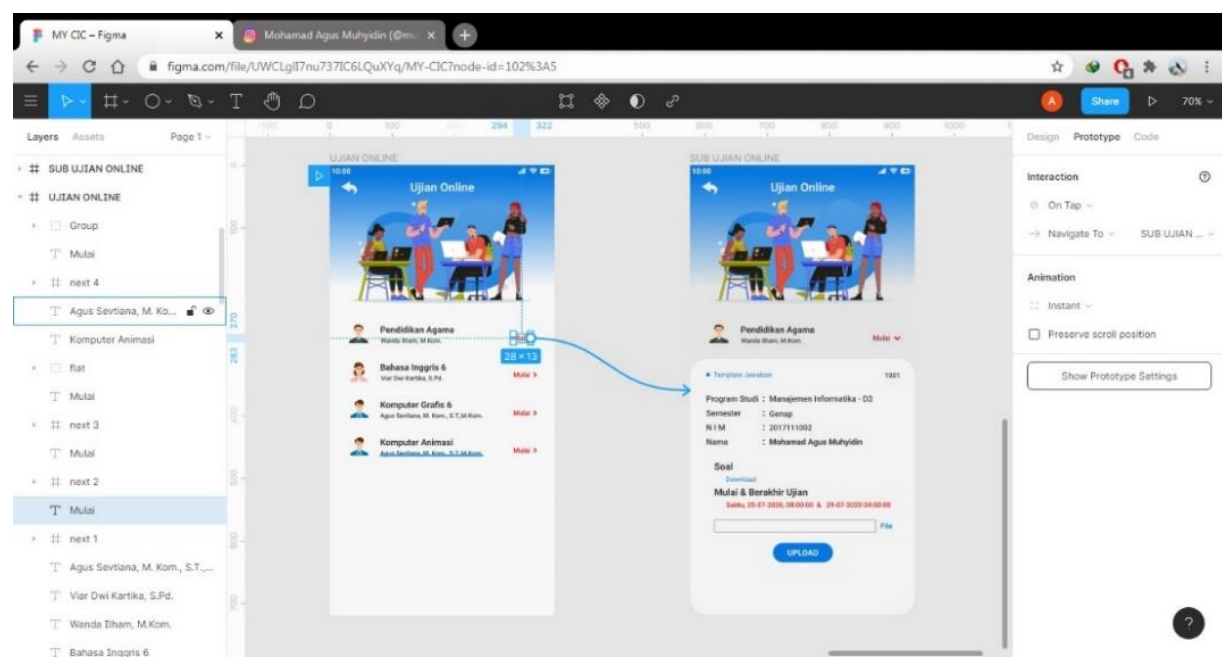

Gambar 10. Tampilan Ujian Online > Tampilan Sub Ujian Online 


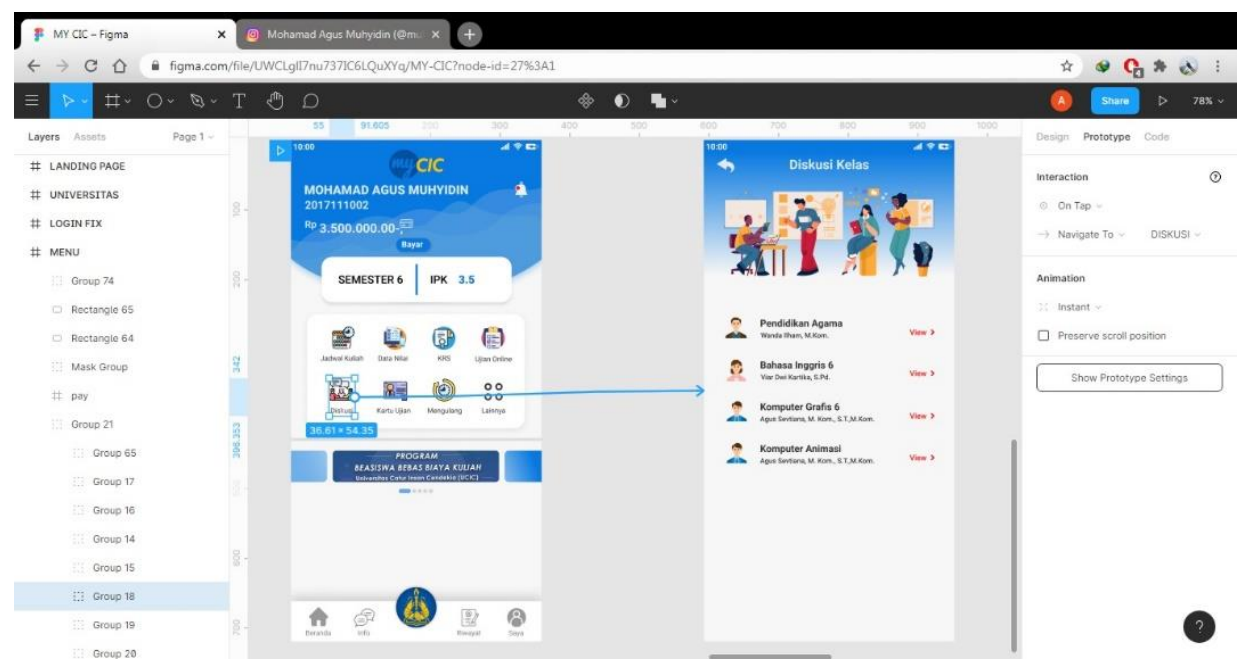

Gambar 11. Tampilan Menu Utama > Diskusi Kelas

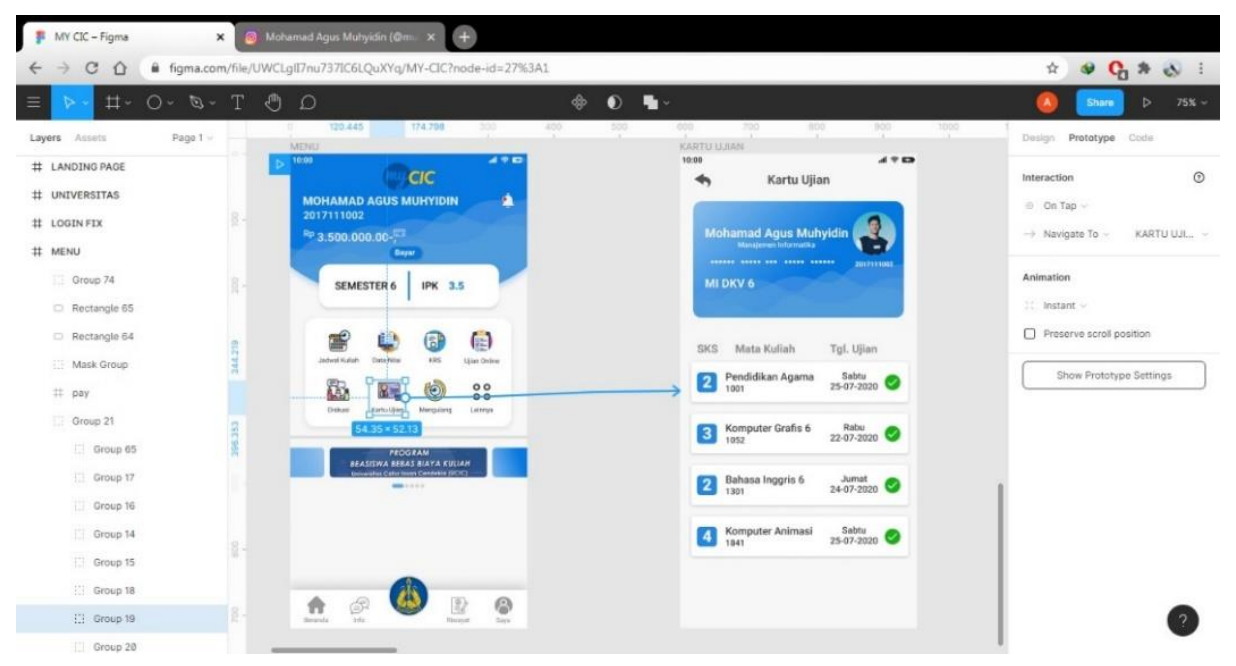

Gambar 12. Tampilan Menu Utama > Tampilan Kartu Ujian 


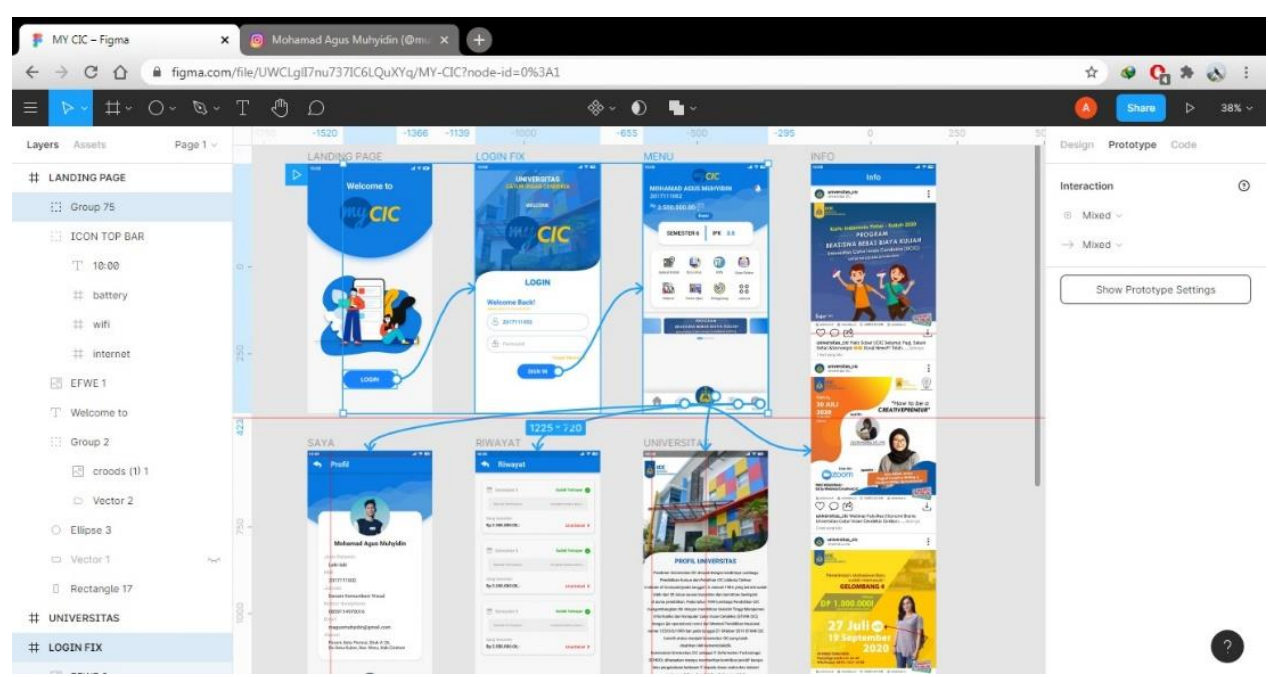

Gambar 13. Tampilan Aplikasi MY CIC

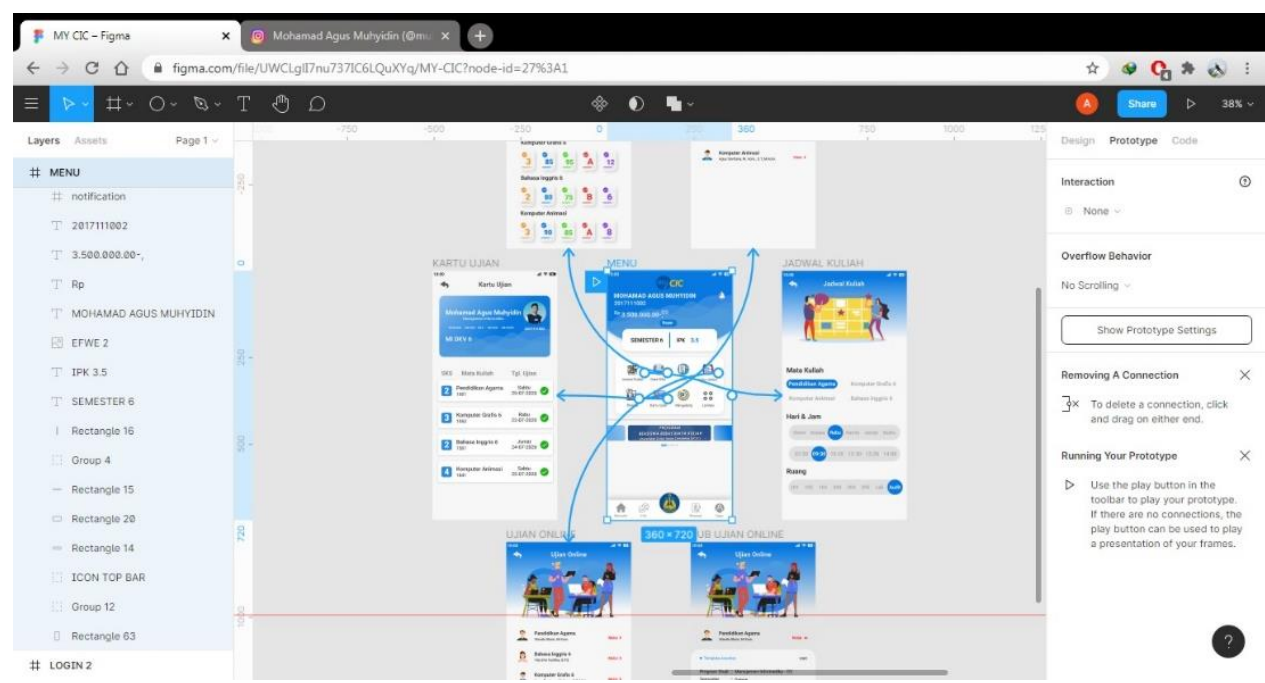

Gambar 14. Tampilan Aplikasi MY CIC

3.2. Hasil tampilan menggunakan smartphone
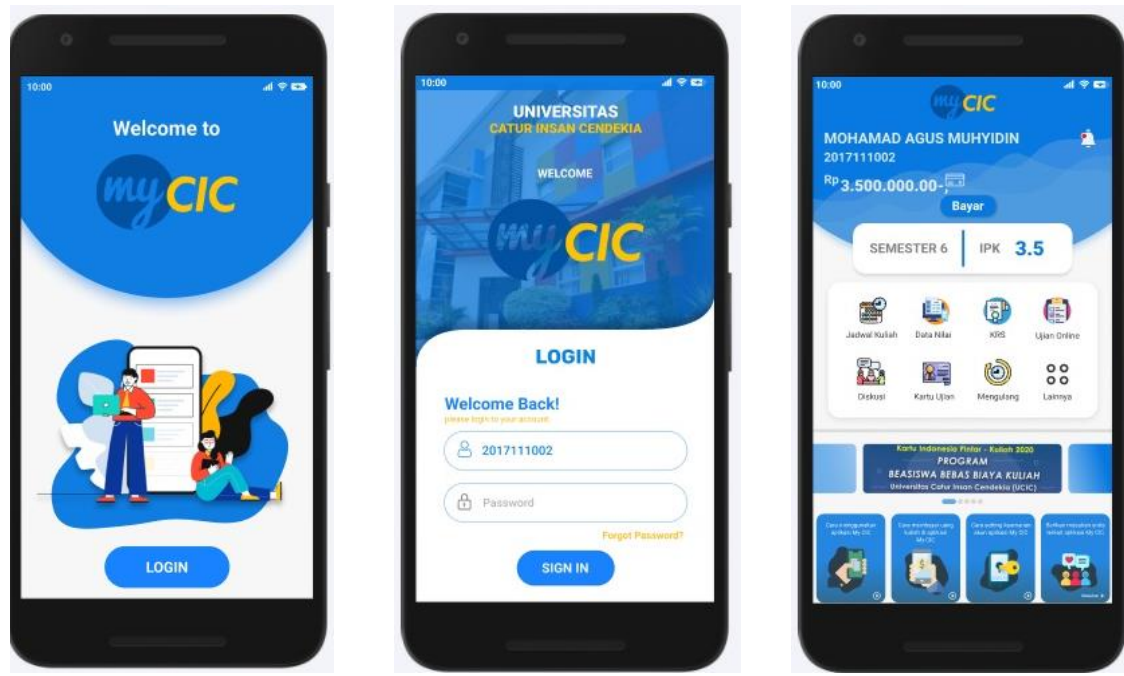

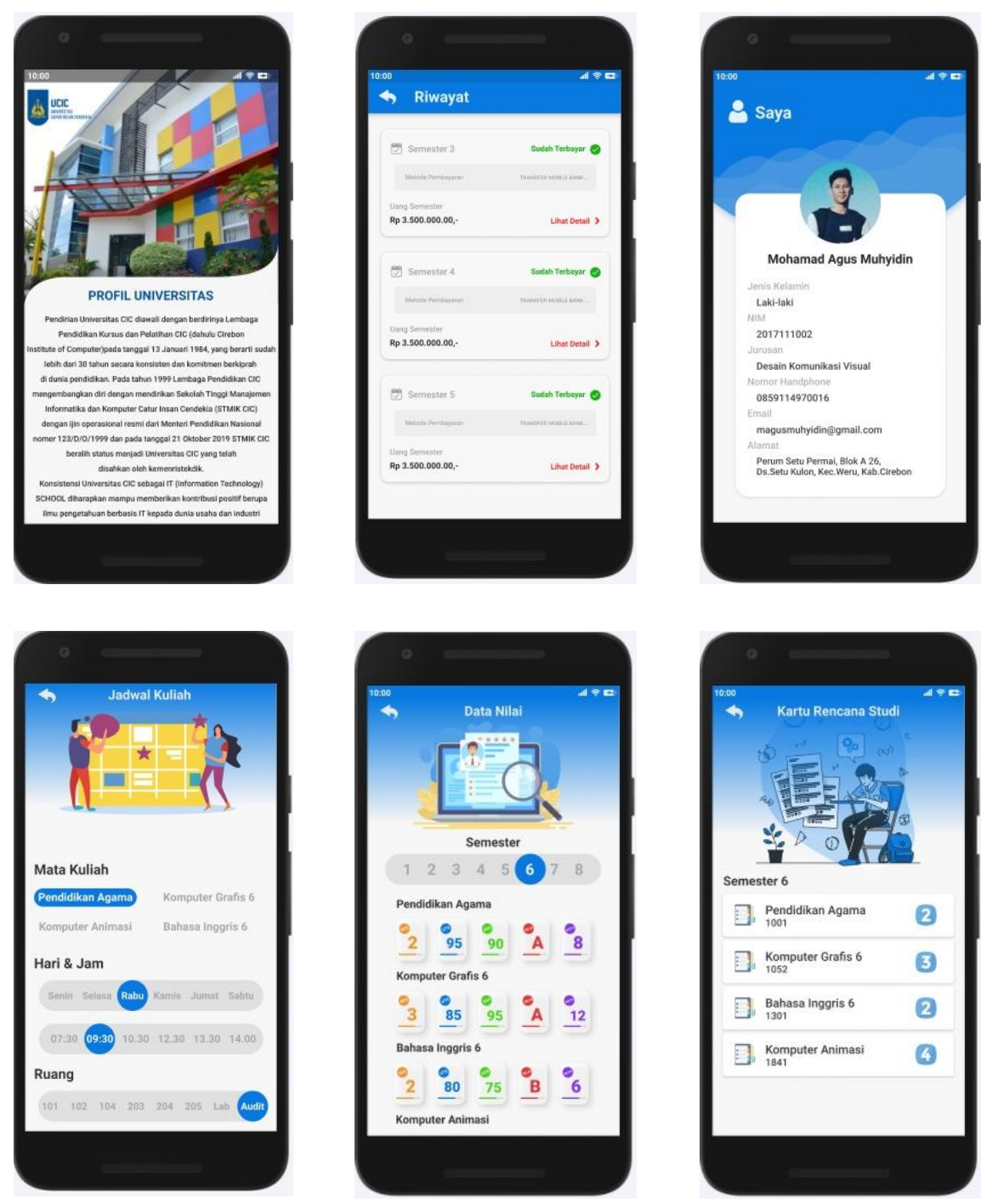

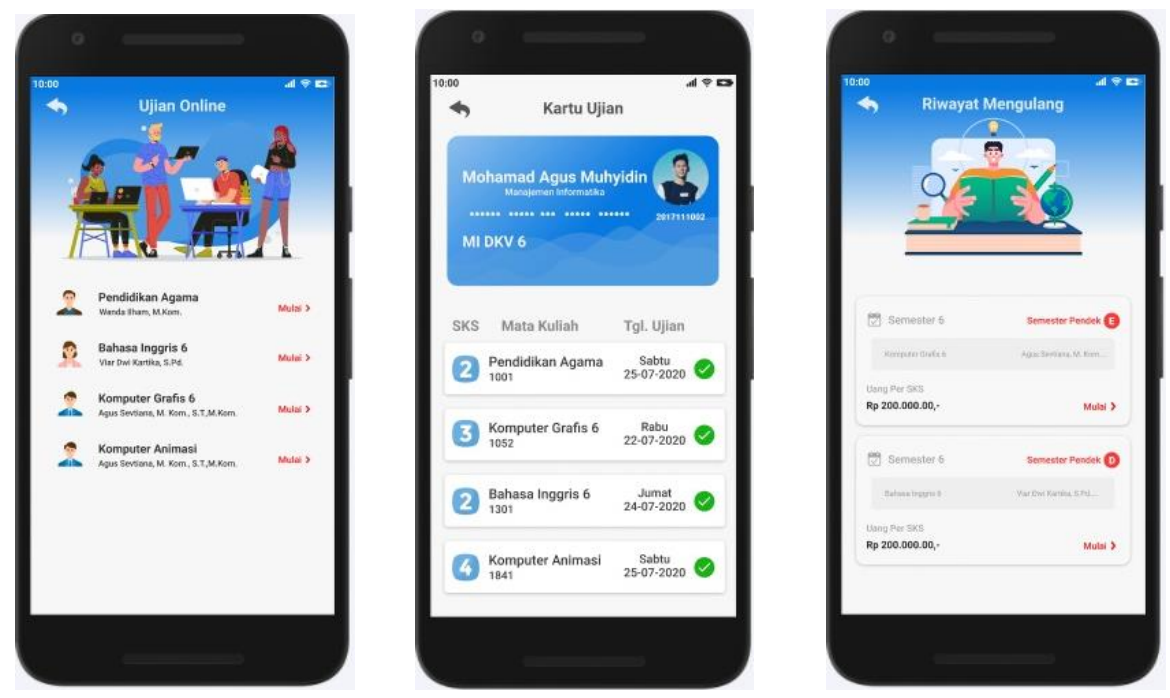

Gambar 15. Prototype Aplikasi MY CIC

\section{KESIMPULAN}

Berdasarkan hasil observasi dalam mendapatkan informasi di kampus Universitas Catur Insan Cendekia, serta perancangan dan implementasi desain user interface dan user experience prototype aplikasi MY CIC, maka penulis dapat memberikan kesimpulan sebagai berikut :

1. Website editing Figma dapat digunakan untuk mendesain tampilan web atau aplikasi My CIC dengan user interface yang menarik, modern dan minimalis.

2. Dalam penelitian ini penulis menghasilkan sebuah prototype aplikasi My CIC yang kompatibel dengan mobile device.

3. Dalam dunia digital yang semakin berkembang ini, membuat dan mengembangkan sebuah aplikasi bukan hal yang sulit di lakukan saat ini, karena informasi terkait teknologi semakin berkembang sangat pesat dan mudah di pelajari oleh siapapun. Sehingga saat ini banyak bermunculan berbagai macam aplikasi yang berfokus di bidang ekonomi, sosial, pemerintahan, maupun bidang pendidikan.

\section{DAFTAR PUSTAKA}

Sumber Buku :

[1] Adi Kusrianto, 2007. "Pengantar Desain Komunikasi Visual".

[2] Al bahra bin Ladjamudin, (2005:39). "Analisis desain dan sistem informasi".

[3] Deddy award widya laksana, (2010:30). "Pengantar Desain Grafis".

[4] Dendy triadi, 2010. "Memahami Teori dan Praktek Iklan Media Lini Bawah".

[5] Jogiyanto, 2005. "Analisis dan Desain".

[5] Metode Riset Untuk Desain Komunikasi Visual, 2010.

\section{Sumber Jurnal :}

[1] Jurnal Fajar agung rahmatullah "perancangan video dokumentasi paket tour wisata sebagai mediapromosi pada bhinneka pariwisata (2019)".

[2] Jurnal stie semarang, vol 6, no 3, edisi oktober 2014 (issn : 2252 - 7826)

[3] Jurnal Rauffauzan 24909-5 Unikom

[4] Jurnal Wisnu tri wibowo (repository.amikom.ac.id > files >Publikasi_11.11.5274.pdf) 